\title{
Mesto popularne muzike u sistemu zaštite kulturne baštine na primeru saradnje Narodne biblioteke Srbije i Zadužbine Milana Mladenovića
}

\author{
Place of the Popular Music in the System of Cultural Heritage Protection - The Example of \\ Cooperation between National Library of Serbia and Milan Mladenović Endowment
}

\author{
Maša Miloradović \\ Narodna biblioteka Srbije, Beograd, Srbija / National Library of Serbia, Belgrade, Serbia \\ masa.miloradovic@nb.rs
}

Informacije o članku / Article Info

Primljen / Received 1. 9. 2020.

Prihvaćen / Accepted 30. 10. 2020.

Dostupan online / Available online: 15. 12. 2020

Ključne reči / Keywords:

popularna muzika, kulturna baština, zaštita nasleđa, javno-privatna saradnja, Narodna biblioteka Srbije, Zadužbina Milana Mladenovića popular music, cultural heritage, heritage protection, public-private cooperation, National Library of Serbia, Milan Mladenović Endowment

Kao jedna od centralnih baštinskih institucija u Republici Srbiji, Narodna biblioteka Srbije obavlja poslove od opšteg interesa u zaštiti stare i retke bibliotečke građe (Zakon o staroj i retkoj bibliotečkoj građi 2011, čl. 5). U tom smislu bavi se, pre svega, pronalaženjem, prikupljanjem, čuvanjem, zaštitom i korišćenjem građe, ali i pružanjem stručne pomoći sopstvenicima stare i retke bibliotečke građe. $\mathrm{Na}$ osnovu ugovora sa pojedincima i institucijama Narodna biblioteka Srbije ostvaruje saradnju na polju zaštite pokretnih kulturnih dobara - bilo da sa svojim stručnjacima deluje na polju fizičke zaštite kroz proces restauracije i konzervacije, da se angažuje u projektima digitalizacije određenih korpusa građe ili na druge načine.

Razgranata delatnost Narodne biblioteke Srbije u oblasti zaštite kulturne baštine proširena je $u$ junu 2019. godine potpisivanjem Ugovora o saradnji Narodne biblioteke Srbije i Zadužbine Milana Mladenovića. "U znak poštovanja i sećanja na istaknutog jugoslovenskog muzičara, Zadužbina je Narodnoj biblioteci Srbije poverila na staranje vrednu građu koju čine lični predmeti i dokumenti, knjige, ruko-
As one of the central heritage institutions in the Republic of Serbia, the National Library of Serbia performs activities of general interest in the preservation of old and rare library materials (Zakon o staroj i retkoj bibliotečkoj građi (Law on old and rare library materials), § 5). For this purpose, it deals, first of all, with finding, collecting, holding, preserving and using materials, but also with providing professional assistance to owners of old and rare library materials. Based on agreements with individuals and institutions, the National Library of Serbia cooperates in the field of preservation of movable cultural property - whether it works with its experts in the field of physical preservation through the process of restoration and conservation, to engage in projects of digitization of certain corpus of materials, or in other ways.

The branched activity of the National Library of Serbia in the field of cultural heritage preservation was expanded in June 2019 with the signing of the Agreement on Cooperation between the National Library of Serbia and the Milan Mladenović Endowment. "As a sign of respect and memory of 
pisi, plakati, fotografije, audio i video materijali i druge vrste građe iz zaostavštine umetnika. Ugovor su potpisali upravnik Narodne biblioteke Srbije, Laslo Blašković, i upraviteljka Zadužbine Milana Mladenovića, Aleksandra Ćebić." (Narodna biblioteka Srbije 2019b).

Ovim činom uobičajene prakse pravnog regulisanja saradnje napravljen je iskorak tradicionalne institucije zaštite, kakva je Narodna biblioteka Srbije, prema bavljenju stvaralaštvom koje se još uvek ne podrazumeva za kulturnu baštinu. To je tek prvi korak ulaska tzv. "popularne kulture" u ustanove zaštite. ${ }^{1}$ Za određeni proizvod ili delo "popularne kulture" postoje vrlo velike razlike i potrebno je opisati, razvrstati, oceniti i doneti vrednosni sud za njih isto kao i za bilo koje delo tzv. "visoke" kulture.

Milan Mladenović, pesnik i muzičar, dobro je poznat generacijama koje su stasavale od početka osamdesetih godina prošlog veka u Jugoslaviji. Rođen u Zagrebu, prve akorde na gitari je naučio i prve stihove napisao u Sarajevu, a kao stvaralac stasao je i afirmisao se u Beogradu, u vreme kada je muzička scena bila vrlo živa. Sastav sa kojim je počeo da nastupa bio je "Limunovo drvo", u muzičkom svetu postao je poznat sa najinventivnijom grupom novog talasa "Šarlo akrobata", a vrhunac stvaralačke snage i popularnost stekao je kao vođa sastava "Katarina Druga", tj. kasnije "Ekaterina Velika". Pisao je muziku za pozorište, a ostvario se i u nekoliko igranih filmova. Ostao je upamćen i po izrazitom antiratnom angažmanu na početku jugoslovenskih ratova, sve do prerane smrti 1994. godine.

U tom smislu, stvaralaštvo Milana Mladenovića imaće važnu ulogu u razumevanju i tumačenju jugoslovenske kulturne scene s kraja 20. veka - njegova poezija i muzika nisu ostale samo u sećanju jedne generacije, već su ušle u javni diskurs. Stihovi pesme "Zemlja" čiji su autori Milan Mladenović i Margita Stefanović - "Ovo je zemlja za nas", postali su referentni - naslov jedne emisije Radio Televizije Beograd glasi - "Mesto za nas", a prati je i muzička tema ove kompozicije. U svakodnevnoj javnoj komunikaciji i obraćanju prepoznaje se upotreba upravo ovih stihova. Pesma "Šarla akrobate" "Mali čovek želi preko crte", kao slika osamdesetih godina u Jugoslaviji, oživljena je u novom vremenu i prostoru kroz muzičko-scenski performans pozorišne trupe "Montažstroj" iz Zagreba, izveden

Termin "popularna kultura" ovde je upotrebljen sasvim uslovno, bez svih pozitivnih ili negativnih socio-kulturnih konotacija, već kao oznaka kulturnog sadržaja kao oličenja jednog vremena i određene generacije, koji još uvek nije dobio mesto u institucijama kulture. $\mathrm{O}$ tome: Frit 2012, 362. the prominent Yugoslav musician, the Endowment entrusted the National Library of Serbia with valuable material consisting of personal items and documents, books, manuscripts, posters, photographs, audio and video materials and other types of material from the artist's legacy. The agreement was signed by the Director of the National Library of Serbia, Laslo Blašković, and the Directress of the Milan Mladenović Endowment, Aleksandra Ćebić." (Narodna biblioteka Srbije 2019b).

With this act of the usual practice of legal regulation of cooperation, a step forward was made by the traditional institution of preservation, such is the National Library of Serbia, towards dealing with creativity that is still not considered as cultural heritage. This is only the first step in entering the so-called "Popular culture" in preservation institutions. ${ }^{1}$ There are very big differences in a certain product or work of "popular culture", and it is necessary to describe, classify, evaluate and make a value judgment just like for any work of the so-called "high" culture.

Milan Mladenović, a poet and musician, is well known to generations that have matured in Yugoslavia since the early 1980s. Born in Zagreb, he learned the first chords on the guitar, and wrote the first verses in Sarajevo, and as a creator he grew up and established himself in Belgrade, at a time when the music scene was very lively. The band which he started performing with was "Limunovo drvo" (Lemon tree), in the music world he became known with the most inventive group of the new wave "Šarlo akrobata" (Charlot the Acrobat), and gained the peak of creative power and popularity as the leader of the band "Katarina Druga" (Catherine II), i.e. later "Ekaterina Velika" (Catherine the Great). He wrote music for the theatre, and accomplished himself in several feature films too. He was also remembered for his strong anti-war engagement at the beginning of the Yugoslav wars, until his untimely death in 1994.

In that sense, Milan Mladenović's work will play an important role in understanding and interpreting the Yugoslav cultural scene from the end of the 20th century - his poetry and music have not only remained in the memory of one generation, but have entered into public discourse. Verses of the song "Zemlja" (Earth) whose authors are Milan Mladenović and Margita Stefanović - "Ovo je zemlja za nas" (This is the country for us), became a reference

\footnotetext{
The term "popular culture" is used here quite conditionally, without all the positive or negative socio-cultural connotations, but as a designation of cultural content as the embodiment of a one period and a certain generation, which has not yet gained a place in cultural institutions. About: Frit 2012, 362.
} 
premijerno 2014. godine, a koji problematizuje norme i "crte društvenih zadatosti". Ne treba posebno spominjati ni ponovljena muzička izdanja, štampanje zbirki pesama, biografija, brojne dokumentarne filmove i emisije posvećene Milanu Mladenoviću i grupama u kojima je stvarao, kao ni brojne muzičke sastave koji se bave koncertnim i klupskim izvođenjem ove muzike.

Ime Milana Mladenovića upisano je u sećanje na taj način što ga je ponelo nekoliko ulica u više gradova. Tako u Beogradu postoje Plato Milana Mladenovića, Ulica Milana Mladenovića u naselju Zemun-polje, u Zagrebu i Podgorici, Prolaz Milana Mladenovića u Novom Sadu. U mnogim gradovima bivše Jugoslavije sećanje na popularne muzičare formalizovano je odlukama o dodeli naziva ulica po pojedinim ličnostima. U Beogradu su to Čavketov pasaž, ${ }^{2}$ Plato Neše Radulovića, ${ }^{3}$ u Novom Sadu - pasaž koji spaja ulice Poštansku i Jevrejsku nazvan je Prolazom Pekinške patke, u novosadskom Limanskom parku jedan plato nosi ime Mitra Subotića Sube. ${ }^{4}$ U Puli odnedavno postoje Poljana Serđa Blažića Đosera $^{5}$ i Stube Branka Črnca Tuste. ${ }^{6}$ Ova vrsta memorijalizacije relativno brzo se sprovodi, jer je lokalnog karaktera. Ipak, ostaje dilema da li davanje naziva ulicama u zabačenim delovima grada na dobar način ispunjava funkciju memorijalizacije. $U$ Sarajevu je imenovanje ulice po čuvenom pevaču i članu grupe "Indeksi" Davorinu Popoviću, u jednoj od centra grada udaljenoj i skrajnutoj ulici, izazvalo, prema pisanju štampe, dosta negativnih reakcija građana, a najpre same njegove porodice. Štampa beleži i neuspeli pokušaj davanja imena novosadskoj ulici po Džonu Lenonu (Vrzić 2002). Kritičke stavove o ovom pitanju imaju i pojedini antropolozi. Baveći se pojmom arhitekstura, kojim označavaju ukupnost urbane arhitekture i teksta koji je označava, smatraju da su "nazivi gradskih ulica specifičan tekst nacionalne naracije, mjesta gdje se strukture vladajuće ideologije susreću s praksom svakodnevnoga života" (Rihtman Auguštin 2000, 51); "simbolični iskaz ideološko-političkoga programa; svaka promjena u njemu uvijek je borba za istiskivanje jednoga a nametanje drugoga sjećanja,

\footnotetext{
Goran Čavajda Čavke (1962-1997), bubnjar i član beogradske grupe "Električni orgazam"

3 Nenad Radulović (1959-1990), muzičar, pesnik i vođa beogradske grupe "Poslednja igra leptira"

4 Mitar Subotić Suba (1961-1999), pseudonim Rex Ilusivii, muzičar, kompozitor i producent iz Novog Sada

5 Sergio Blažić (1951-1987), muzičar i pevač pulske grupe "Atomsko sklonište"

6 Branko Črnac Tusta (1955-2012), vođa pulske pank-grupe "KUD Idijoti”
}

- the title of one show of Radio Televizija Beograd (Radio Television Belgrade) reads - "Mesto za nas" (A place for us), and is accompanied by the musical theme of this composition. In everyday public communication and addressing, the use of these verses is recognized. The song of "Šarlo akrobata" (Charlot the Acrobat) "Mali čovek želi preko crte" (The little man wants across the line), as a picture of the 1980 s in Yugoslavia, was revived in a new time and space through the musical-scenic performance of the theatre troupe "Montažstroj" from Zagreb, premiered in 2014, which problematizes norms and "features of social tasks". Not to mention repeated music releases, printing collections of songs, biographies, numerous documentaries and shows dedicated to Milan Mladenović and the groups in which he created, as well as numerous musical ensembles engaged in concert and club performances of this music.

The name of Milan Mladenović is inscribed in the memory in the manner that it was taken by several streets in several cities. Thus, in Belgrade there is Plato Milana Mladenovića (Plateau of Milan Mladenović), Ulica Milana Mladenovića (Street of Milan Mladenović) in community Zemun-polje, in Zagreb and Podgorica, Prolaz Milana Mladenovića (Passage of Milan Mladenović) in Novi Sad. In many cities of the former Yugoslavia, the memory of popular musicians has been formalized by decisions on naming streets after certain personalities. In Belgrade they are Čavketov pasaž ${ }^{2}$ (Čavke's passage), Plato Neše Radulovića ${ }^{3}$ (Plateau of Nešo Radulović) in Novi Sad - a passage connecting the streets Poštanska ulica i Jevrejska ulica was named Prolaz Pekinške patke (Passage of Peking Duck), in Limanski park in Novi Sad, a plateau has the name Mitar Subotić Suba. ${ }^{4}$ In Pula recently exist Poljana Serđo Blažić Đoser $^{5}$ (Plain of Sergio Blažić Đoser) and Stube Branka Črnca Tuste ${ }^{6}$ (Stairs of Branko Črnac Tusta). This type of memorialization is carried out relatively quickly, because it is of a local character. However, the dilemma remains whether naming streets in remote parts of the city fulfills the function of memorialization in a good way. In Sarajevo, the naming of the street after the famous singer and member of the

\footnotetext{
2 Goran Čavajda Čavke (1962-1997), drummer and member of the Belgrade band "Električni orgazam" (Electric Orgasm)

Nenad Radulović (1959-1990), musician, poet and leader of the Belgrade band "Poslednja igra leptira" (Last Dance of a Butterfly)

4 Mitar Subotić Suba (1961-1999), pseudonym Rex Ilusivii, musician, composer and producer from Novi Sad

5 Sergio Blažić (1951-1987), musician and singer of the Pula band "Atomsko sklonište" (Atomic Shelter)

6 Branko Črnac Tusta (1955-2012), leader of the Pula punk band "KUD Idijoti" (Cultural Artistic Society "Idiots")
} 
odnosno znak da je nova vlast ovladala prostorom" (Lovrenović 2016). U tom kontekstu, nije zanemarljiva ni geografska pozicija novoimenovane ulice.

Pored davanja naziva ulica, postoje i sporadični primeri kad je ime ličnosti iz sveta popularne kulture, pre svega muzike, dato i nekoj ustanovi - kao što u Beogradu nekadašnja Ustanova kulture Palilula odskora nosi naziv Centar za kulturu "Vlada Divljan".? U Kruševcu se nije odmaklo dalje od inicijative da srednjoškolski internat "Pane Đukić Limar" promeni ime u "Milan Mladenović", u kojoj je značaj argument trebalo da bude i činjenica da je Milanov otac iz Kruševca (Rizinger 2020, 206). Korak dalje, sa heritološkog stanovišta, otišle su gradske vlasti u Rijeci, kada su pre nekoliko godina proglasile grafit prve riječke, a i jedne od prvih jugoslovenskih pank grupa "Paraf", za kulturno dobro od lokalnog značaja, jer "svjedoči o počecima i razvoju riječkog, jugoslavenskog i istočnoevropskog panka, te slovi kao važan spomenik popularne kulture" (Grad Rijeka 2018).

Više je primera ideja koje su ostale neostvarene ili kratkog trajanja, kao što je bilo otvaranje Audio-vizuelnog muzeja Laboratorije zvuka na Petrovaradinskoj tvrđavi, u toku trajanja Egzit festivala 2013. godine. Povremeno se organizuju izložbe, koncerti i multimedijalni događaji, osmišljeni u svrhu (pod) sećanja na pojedinačne autore ili sastave, a u virtuelnom svetu postoji Rok muzej (2015). Muzej džeza (Matović 2020) za sada postoji samo kao ideja.

Sa sigurnošću možemo reći da je stav naslednika prema zaostavštini presudan za njenu dalju sudbinu. Autori (ali i njihovi naslednici) koji se bave određenom performativnom vrstom stvaralaštva nisu uvek svesni potrebe čuvanja svoga stvaralaštva. "Osim retkih primera, ljudi vezani za pank nisu ostavili arhivske zbirke koje sadrže tradicionalnu građu, kao što su prepiska ili dnevnici". ${ }^{8}$

Ideja o osnivanju Zadužbine Milana Mladenovića potekla je od Milanove majke Danice, kao njegovog zakonskog naslednika, što je formulisano u njenom testamentu (Zadužbina Milana Mladenovića. "O zadužbini"). To je bio presudan korak u integralnom očuvanju zaostavštine njenog sina. Podstaknuti testamentarnom željom Danice Mladenović, Milanovi prijatelji i kolege osnovali su Zadužbinu u skladu sa rečima Milanovog kolege i prijatelja, a

\footnotetext{
Vlada Divljan (1958-2015), rok-muzičar i kompozitor, najpoznatij kaočlan beogradske muzičke grupe "VIS Idoli"

8 Redak primer tradicionalne arhivske zbirke koja se tiče panka je Zbirka Ričarda Hela u jednoj od biblioteka Njujorškog univerziteta. Videti: Turrini 2013.
}

group "Indeksi" (Indexi), Davorin Popović, in one of the city's distant and remote street, caused, according to the press, a lot of negative reactions from citizens, especially from his family. The press also notes the failed attempt to name the street in Novi Sad after John Lennon (Vrzić 2002). Critical views on this issue also have some anthropologists. Dealing with the term of architexture, which denotes the totality of urban architecture and the text that denotes it, they consider that "the names of city streets - are a specific text of the national narrative, places where the structures of the ruling ideology meet the practice of everyday life" (Rihtman Auguštin 2000, 51); "a symbolic statement of the ideological-political program; every change in it is always a struggle to push out one memory and to impose another memory, that is, a sign that the new government has taken over the space." (Lovrenovic 2016). In that context, the geographical position of the newly named street is not negligible either.

In addition to naming the streets, there are sporadic examples when the name of a person from the world of popular culture, primarily music, is given to an institution - such as the former Ustanova kulture Palilula (Palilula Cultural Institution) in Belgrade was recently named as Centar za kulturu "Vlada Divljan" (the Cultural Center Vlada Divljan). ${ }^{7}$ In Kruševac, they did not move beyond the initiative to change a name of a high school boarding school "Pane Đukić Limar" to "Milan Mladenović", in which the significant argument should have been the fact that Milan's father was from Kruševac (Rizinger 2020, 206). From a heritological point of view, the city authorities in Rijeka made a step further, when a few years ago they declared the graffiti of the first Rijeka's, and one of the first Yugoslav punk groups "Paraf" for a cultural property of local significance, because "it testifies to the beginnings and development of Rijeka, Yugoslav and Eastern European punk, and is known as an important monument of popular culture." (Grad Rijeka 2018).

There are several examples of ideas that have remained unfulfilled or short-lived, such as the opening Audio-vizuelni muzej Laboratorije zvuka (Audio-visual museum of the Sound Laboratory) at Petrovaradinska tvrđava (Petrovaradin Fortress), during the Exit festival in 2013. Occasionally, exhibitions, concerts and multimedia events are organized, designed to remind / remember individual au-

\footnotetext{
Vlada Divljan (1958-2015), rock musician and composer, best known as a member of the Belgrade music band "VIS Idoli" (The Idols)
} 
sad jednog od članova UO Zadužbine, Zorana Kostića Caneta: "Važna je jedna stvar - mi polako odlazimo, a mi smo jedna epoha" (Rigonat 2004, 156). Zadužbina je osnovana "na neodređeno vreme, sa ciljem da se umetnička, autorska i lična zaostavština Milana Mladenovića sačuva kao celina i da se, kao zadužbina, nameni za kulturne i humanitarne potrebe" (Zadužbina Milana Mladenovića 2018). Osnovnu imovinu Zadužbine čine Mladenovićevi lični predmeti, rukopisi, prepiska, knjige, notni zapisi, audio i video-snimci i fotografije. Narodna biblioteka Srbije, kao državna institucija, obezbeđuje stručno bavljenje ovom celinom (kataloška obrada, konzervacija), a garantuje i trajnost njene zaštite, za razliku od ustanova privatnog karaktera, sa ograničenim trajanjem ili izvorima finansiranja.

Prvi kontakt sa Narodnom bibliotekom Srbije i njenim Odeljenjem za konzervaciju Zadužbina je učinila tražeći mogućnosti da se zaštiti građa na papiru (rukopisi i fotografije). U susretu Zadužbine i Narodne biblioteke Srbije rodila se ideja da se sama građa trajno smesti u Biblioteku. Ovakav sticaj okolnosti potvrđuje mišljenje da ustanove zaštite treba da imaju aktivniju ulogu u otkrivanju baštine (Britta et all. 2013). Narodnoj biblioteci Srbije su predati rukopisi, dokumenti, knjige, audio i video-snimci, fotografije, plakati, lični predmeti, pisaći sto i razna sitna štampana građa. Prema praksi Narodne biblioteke Srbije, celina je dobila svoju signaturu po inicijalima autora i započeta je stručna obrada. Knjige, audio i video-snimci, fotografije, plakati i sitna građa kataloški su obrađeni u COMARC formatu u Kooperativnom bibliografskom sistemu COBISS.SR. Rukopisna građa se obrađuje prema arhivističkim standardima u okviru Elektronskog kataloga rukopisa i arhivalija AtoM NBS (EKRAAN). ${ }^{9}$ Rukopisi su razvrstani na uobičajene celine - rukopise, prepisku, lična dokumenta i razno. Na ovaj način sistematizovana i stručno obrađena građa biće dostupna kroz pomenute kataloge $i$ to predstavlja osnovu za dalje proučavanje i tumačenje Milanovog dela i vremena. Planira se digitalizacija kolekcije, čija će dostupnost na taj način biti proširena i u virtuelni svet. Formiranjem spomenkutka posvećenog Milanu, gde će biti izložen izbor obrađene građe, Narodna biblioteka Srbije proširiće svoj krug korisnika.

U okviru saradnje Zadužbine Milana Mladenovića i Narodne biblioteke Srbije održana je manifestacija dodele prve Nagrade "Milan Mladenović", na dan

\footnotetext{
O ovom programu za obradu rukopisa i njegovom razvoju više u: Obradović 2018.
}

thors or ensembles, and in the virtual world there is a Museum of Rock (Rok muzej 2015). Jazz museum (Matović 2020) for now exists only as an idea.

We can say with certainty that the attitude of the successors towards the legacy is crucial for its further destiny. Authors (but also their successors), who deal with a certain performative type of creativity, are not always aware of the need to preserve their creativity. "Apart from rare examples, people related to punk have not left archival collections containing traditional material, such as correspondence or diaries." 8

The idea of founding the Milan Mladenović Endowment came from Milan's mother Danica, as of his legal successor, which was formulated in her will (Zadužbina Milana Mladenovića. "O zadužbini”"). It was a crucial step in the integral preservation of her son's legacy. Encouraged by Danica Mladenović's testamentary wish, Milan's friends and colleagues founded the Endowment in accordance with the words of Milan's colleague and friend and now one of the members of the Board of the Endowment, Zoran Kostić Cane: "One thing is important - we are slowly leaving, and we are one epoch" (Rigonat 2004, 156). The Endowment was established "indefinitely, with the aim of preserving the artistic, authorial and personal legacy of Milan Mladenović as a whole and, as an endowment is intended for cultural and humanitarian needs." (Zadužbina Milana Mladenovića 2018). The basic property of the Endowment consists of Mladenović's personal items, manuscripts, correspondence, books, music sheets, audio and video recordings and photographs. The National Library of Serbia, as a state institution, provides professional handling with this unity (cataloguing, conservation), and guarantees the permanence of its preservation, unlike private institutions, with limited duration or sources of funding.

The first contact with the National Library of Serbia and its Department for Conservation was made by the Endowment, looking for opportunities to protect the material on paper (manuscripts and photographs). In the meeting between the Endowment and the National Library of Serbia, the idea was born to permanently place the material in the Library. This combination of circumstances confirms the opinion that preservation institutions should play a more active role in heritage discovery (Britta et all. 2013). Manuscripts, documents, books, audio and video recordings, pho-

\footnotetext{
A rare example of a traditional archival collection concerning punk is the Collection of Richard Hell in one of the libraries of New York University. See: Turrini 2013.
} 
Milanovog rođendana 21. 9. 2019. godine (Narodna biblioteka Srbije 2019b). Krajem avgusta 2020. godine održana je onlajn tribina "Poštenije nisam mogao da potrošim godine" o značaju rukopisne zaostavštine Milana Mladenovića.

Pre nešto više od petnaest godina Narodna biblioteka Srbije dobila je na čuvanje legat majstora fotografije i profesora Fakulteta dramskih umetnosti u Beogradu Branibora Debeljkovića (1916-2003). Glavni deo legata čini zbirka njegovih fotografija, tako da je to prvi legat u Narodnoj biblioteci Srbije čiji sadržaj nisu knjige. Ta činjenica je bila podsticajna za naslednike fotografa Ive Eterovića (1935-2001) da njegovu zaostavštinu povere Narodnoj biblioteci Srbije. Slično je i sa kolekcijama ilustracija. Nadamo se da će na isti način saradnja sa Zadužbinom Milana Mladenovića i činjenica da je njegova zaostavština smeštena u Narodnu biblioteku Srbije biti podsticajna za imaoce ili naslednike kolekcija slične provenijencije. tographs, posters, personal items, writing desk and various small printed materials were handed over to the National Library of Serbia. According to the practice of the National Library of Serbia, unit has received its call number based on the initials of the author and the professional processing began. Books, audio and video recordings, photographs, posters and small materials are cataloged in COMARC format in Co-operative Online Bibliographic System COBISS.SR. Manuscripts are processed according to archival standards within the Electronic Catalogue of manuscripts and archival records AtoM NBS (EKRAAN). ${ }^{9}$ The manuscripts are arranged in the usual units - manuscripts, correspondence, personal documents and miscellaneous. In this way, systematized and professionally processed material will be available through the mentioned catalogues and this is the basis for further study and interpretation of Milan's work and time. The digitalization of the collection is planned, whose availability in this way will be extended to the virtual world. The National Library of Serbia will expand its circle of users by forming a memorial corner dedicated to Milan, where a selection of processed materials will be exhibited.

As part of the cooperation between the Milan Mladenović Endowment and the National Library of Serbia, a manifestation was held to award the first "Milan Mladenović" Award, on the day of Milan's birthday, September 21, 2019 (Narodna biblioteka Srbije 2019a). At the end of August 2020, an online public lecture was held "Poštenije nisam mogao da potrošim godine" (I couldn't spend all those years more honestly) on the significance of the manuscript legacy of Milan Mladenović.

A little more than fifteen years ago, the National Library of Serbia received the legacy of the master of photography and professor of the Faculty of Dramatic Arts in Belgrade, Branibor Debeljković (1916-2003). The main part of the legacy is a collection of his photographs, so it is the first legacy in the National Library of Serbia, which content are not books. That fact was an incentive for the successors of photographer Ivo Eterović (1935-2001) to entrust his legacy to the National Library of Serbia. It is similar with the collections of illustrations. We hope that in the same way, the cooperation with the Milan Mladenović Endowment and the fact that his legacy is placed in the National Library of Serbia will be an incentive for the owners or successors of collections of similar provenance.

\footnotetext{
More about this program of manuscript processing and its development in: Obradović 2018.
} 


\section{Izvori i literatura / Sources and literature}

- Britta, Rudolff et al. 2013. Understanding Heritage: Perspectives in Heritage Studies. De Gruyter.

- EKRAAN. Elektronski katalog rukopisa i arhivalija AtoM NBS. http://arhivalije.nb.rs/.

- Frit, Sajmon. 2012. "Dobra, loša i osrednja: odbrana popularne kulture od populista" U Studije kulture. Beograd: Službeni glasnik.

- Grad Rijeka. 2018. "Obnovljeno zaštićeno kulturno dobro - grafit 'Paraf punk"' Grad Rijeka, 20. 4. 2018. https://www.rijeka.hr/obnovljenozasticeno-kulturno-dobro-grafit-paraf-punk/. Datum pristupa 4. 4. 2020.

- Lovrenović, Ivan. 2016. "Ivo Žanić: arhitekstura 'zapadnoga' Mostara", 29. 5. 2016. http:// ivanlovrenovic.com/clanci/varia/ivo-zanicarhitekstura-zapadnoga-mostara. Datum pristupa 10. 2. 2020.

- Matović, D. 2020. "Smešten u Kući legata, objediniće zaostavštinu Miše Blama: Beograd dobija Muzej džeza?" Novosti, 4. 2. 2020. https://www.novosti.rs/vesti/naslovna/reportaze/ aktuelno.293.html:845348-Smesten-u-Kucilegata-objedinice-zaostavstinu-Mise-BlamaBeograd-dobija-Muzej-dzeza. Datum pristupa 3. 4. 2020.

- Narodna biblioteka Srbije. 2019a. "Dodela nagrade "Milan Mladenović" 21. 9. 2019. https:// www.nb.rs/events/event.php?id=35635. Datum pristupa 5. 2. 2020.

- Narodna biblioteka Srbije. 2019b. "Saradnja sa Zadužbinom Milana Mladenovića" 20. 6. 2019. https://www.nb.rs/events/event.php?id=35387. Datum pristupa 5. 2. 2020.
- Obradović, Ivan. 2018. "Razvoj elektronskog kataloga rukopisa i arhivalija AtoM NBS" Glasnik Narodne biblioteke Srbije 20: 91-109.

- Rigonat, Flavio. (ur.) 2004. Dečak iz vode: monografija Milana Mladenovića. Beograd: Lom.

- Rihtman, Auguštin. 2000. Dunja Ulice moga grada. Beograd: Biblioteka XX vek.

- Rizinger, Ivan. 2020. Jugosloven K. (Hronika odustajanja 1990-1992). Beograd: Take it or Leave it.

- Rok muzej. 2015. "Krov za davno sazidanu kuću" 18. 10. 2015. http://www.rokmuzej.rs/ krov-za-davno-sazidanu-kucu/. Datum pristupa 3. 4. 2020.

- Turrini, Joseph M. 2013. “'Well I don't care about history': oral history and the making of collective memory in punk rock", Notes 70 (1): 59-77. www.jstor.org/stable/43672697. Datum pristupa 3. 4. 2020.

- Vrzić, Nikola. 2002. "Lenon u Novom Sadu" NIN, 2701 (10. 10. 2002).

- Zadužbina Milana Mladenovića. "O zadužbini”. https://www.milanmladenovic.com/o-zaduzbini/.

- Zadužbina Milana Mladenovića. 2018. "Odluka o osnivanju Zadužbine Milana Mladenovića" https://www.milanmladenovic.com/media/ zaduzbina/odluka-o-osnivanju-zaduzbinemilana-mladenovic.pdf. Datum pristupa 5. 2. 2020.

- Zakon o staroj i retkoj bibliotečkoj građi. 2011. Službeni list Republike Srbije, Br. 52 (2011). 